\title{
Pendekatan Matematika Realistik Untuk Meningkatkan Hasil Belajar Siswa Kelas I Pada Operasi Hitung
}

\author{
Yusmaniar \\ SDN 21 Batang Anai Kabupaten Padang Pariaman
}

\begin{abstract}
Teacher in mathematics learning process of 1st grade at SDN 21 Batang Anai Kabupaten Padang Pariaman used to implement expository method. It caused the learning achievement of students become low. This study is a classroom action research with two cycles that aimed to improve students' learning achievement by implementing realistic mathematics education. Mean of students' learning achievement score in cycle I is 77.2 and 88.2 for cycle II. Hence, realistic mathematics education can improve students' learning achievement.
\end{abstract}

Kata Kunci: learning achievement, RME, mathematics

(i) This is an open access article distributed under the Creative Commons Attribution License, which permits unrestricted use, distribution, and reproduction in any medium, provided the original work is properly cited. (C2017 by author and Indonesian Institute for Counseling, Education and Therapy (IICET).

\section{PENDAHULUAN}

Pembelajaran harus bermakna bagi siswa, untuk itu guru harus mengetahui akan objek yang akan diajarkan sehingga dapat mengajarkan kepada siswa dengan penuh dinamika dan inovasi dalam pembelajaran. Menurut Sri (2006) "Matematika merupakan ilmu pengetahuan yang mempelajari struktur yang abstrak dan pola hubungan yang ada di dalamnya”. Belajar matematika tidak terlepas dari mengajar matematika. Dalam pembelajaran matematika umumnya prestasi belajar matematika siswa termasuk SD relatif rendah. Apalagi penanaman konsep matematika bagi kelas rendah (1, 2, dan 3). Bagi siswa kelas III merupakan masa peralihan dari kelas rendah ke kelas tinggi (4, 5, dan 6). Guru harus memperhatikan bagaimana mengajarkan matematika sesuai dengan kemampuan berfikir siswa agar ke efektifan siswa dalam pembelajaran berhasil dengan baik.

Pembelajaran adalah proses interaksi siswa dengan pendidik dan sumber belajar pada suatu lingkungan belajar. Pembelajaran merupakan bantuan yang diberikan pendidik agar dapat terjadi proses pemerolehan ilmu dan pengetahuan, penguasaan kemahiran dan tabiat, serta pembentukan sikap dan kepercayaan pada siswa. Dengan kata lain, pembelajaran adalah proses untuk membantu siswa agar dapat belajar dengan baik. Jadi dapat disimpulkan bahwa pembelajaran matematika dapat membentuk pola pikir yang sistematis yang dapat digunakan untuk menagtasi persoalan nyata mulai dari konsep sederhana sampai kompleks.

Matematika merupakan ilmu universal yang mendasari perkembangan teknologi modern, mempunyai peranan penting dalam berbagai disiplin dan memajukan daya pikir manusia. Salah satu karakteristik matematika adalah mempunyai sifat yang abstrak, ini menyebabkan banyak siswa mengalami kesulitan dalam belajar Matematika. Hal lain yang menyebabkan sulitnya matematika bagi siswa adalah karena pembelajaran matematika kurang bermakna, jadi pemahaman konsep yang benar sangatlah penting. Untuk memahami konsep yang baru, diperlukan prasyarat konsep 
sebelumnya agar pembelajaran matematika dimengerti oleh siswa, maka perlu penanaman konsep awal yang benar dari guru terutama guru SD.

Pembelajaran matematika haruslah bermakna bagi siswa, supaya siswa tidak mengalami kesulitan dalam mengaplikasikan matematika dalam situasi kehidupan nyata siswa. Guru dalam mengajar matematika di kelas harus mengaitkan pembelajarannya dengan skema yang telah dimiliki oleh siswa dan siswa harus diberikan kesempatan untuk menemukan kembali dan mengkonstruksi sendiri ide-ide matematika tersebut. Fungsi pembelajaran matematika dalam Depdiknas (2003) yaitu: "Mengembangkan kemampuan bernalar melalui kegiatan pendidikan, eksplorasi dan eksperimen sebagai alat memecahkan masalah melalui pola pikir dan model matematika, serta mengembangkan sikap gigih dan percaya diri dalam mengembangkan masalah". Jadi pembelajaran matematika berfungsi untuk mengembangkan kemampuan bernalar dan mengkomunikasikan gagasan melalui kegiatan pendidikan, eksplorasi dan eksperimen sebagai alat memecahkan masalah melalui pola pikir dan model matematika yang dapat berupa kalimat dan persamaan matematika, diagram, grafik, dan simbol.

Untuk menerapkan konsep matematika terutama materi operasi perkalian bilangan cacah dalam kehidupan sehari-hari dapat dilakukan dengan strategi pembelajaran yang mengaitkan dengan dunia nyata sebagai titik tolak dalam belajar matematika, yang dikenal dengan pendekatan matematika realistik. Pembelajaran operasi perkalian bilangan cacah dengan pendekatan matematika realistik, akan memberikan kesempatan kepada siswa untuk menemukan dan mengkonstruksi kembali konsep-konsep matematika sehingga siswa mempunyai konsep pengertian yang kuat. Namun, dalam penyampaian pembelajaran matematika umumnya guru tidak mengaitkan dengan skema yang telah dimiliki oleh siswa dan siswa kurang diberikan kesempatan untuk menemukan kembali dan mengkonstruksi sendiri ide-ide matematika, sehingga menyebabkan siswa belajar secara pasif.

Dari hasil observasi dan wawancara yang penulis laksanakan di SD Unggul Terpadu Padang Pariaman di kelas I, siswa kesulitan dalam pembelajaran operasi perkalian bilangan cacah, karena guru masih belum menggunakan pendekatan realistik. Guru dalam menyampaikan materi pelajaran operasi perkalian bilangan cacah dengan menggunakan metode ceramah dan guru terfokus pada buku paket yang ada. Seperti pada saat guru menjelaskan pembelajaran tentang perkalian siswa mengerti, tetapi setelah guru membuat sosal operasi perkalian bilangan cacah siswa mulai bingung. Hal ini menyebabkan rendahnya hasil pembelajaran siswa, untuk meningkatkan hasil pembelajaran matematika tergantung dari bagaimana guru melaksanakan pembelajaran. Guru harus menciptakan pembelajaran yang menyenangkan bagi siswa. Salah satu cara yaitu dengan menerapkan pendekatan matematika realistik.

Dari hasil pengamatan tersebut, hal ini adalah merupakan masalah yang perlu diatasi. Oleh sebab itu perlu dikembangkan suatu pembelajaran yang tidak membosankan dan membuat siswa lebih tertarik, dengan cara menciptakan lingkungan belajar yang dekat dengan dunia nyata. Kegiatan pembelajaran pendekatan matematika realistik dapat mengarahkan siswa mengaplikasikan teori matematika secara bermakna. Pembelajaran matematika dengan pendekatan matematika realistik, akan memberikan kesempatan kepada siswa untuk menemukan dan mengkonstruksi kembali konsep matematika sehingga siswa mempunyai konsep pengertian yang kuat. Hal tersebut dapat dilakukan dengan mengupayakan berbagai kondisi dan situasi serta permasalahanpermasalahan yang realistik, sehingga pembelajaran bermakna dan membuat siswa tertarik untuk belajar matematika serta dapat meningkatkan hasil pembelajaran.

Pendekatan Realistik yang lebih dikenal dengan Realistic Mathematics Education (RME) pertama kali dikenalkan di Belanda pada tahun 1970 oleh Institut Freudenthal. RME pada dasarnya adalah pemanfaatan realitas dan lingkungan yang dipahami siswa untuk memperlancar proses pembelajaran matematika sehingga dapat mencapai tujuan pendidikan matematika secara lebih baik daripada masa yang lalu Soedjadi (2001). Dengan kata lain pembelajaran matematika dengan RME menuntut siswa untuk aktif membangun sendiri pengetahuannya dengan menggunakan dunia nyata untuk pengembangan ide dan konsep matematika. RME adalah suatu pendekatan pendidikan matematika yang dikembangkan di Netherland (Belanda) oleh Hans Freudental. 
Dalam RME, dunia nyata digunakan sebagai titik awal untuk pengembangan ide dan konsep matematika (Sutarto, 2005). PMR diawali dengan masalah kontekstual yaitu pada pemahaman makna materi pelajaran yang dipelajarinya dengan mengaitkan antara materi yang dipelajari dengan konteks kehidupan mereka sehari-hari, sehingga memungkinkan siswa menggunakan pengalaman atau pengetahuan yang telah dimiliki sebelumnya secara lagsung. Masalah kontekstual tidak hanya berfungsi sebagai sumber pematematikan, tetapi juga sebagai sumber untuk mengaplikasikan kembali matematika. Masalah kontekstual yang diangkat sebagai topik awal pembelajaran, hendaknya masalah sederhana yang dikenali oleh siswa.

\section{METODE}

Penelitian ini dilaksanakan di kelas I SDN 21 Batang Anai Kab. Padang Pariaman. Lokasi ini dipilih sebagai tempat penelitian dengan pertimbangan sebagai berikut. Pertama, guru cenderung menggunakan pembelajaran yang konvensional seperti metode ceramah dan tanya jawab. Kedua, belum pernah dilaksanakan pembelajaran pendekatan matematika realistik dalam pembelajaran matematika. Ketiga, siswa mengganggap matematika pelajaran yang membosankan dan sulit untuk dimengerti. Jenis penelitian ini adalah penelitian tindakan kelas, yaitu proses yang dilakukan perorangan atau kelompok yang menghendaki perubahan dalam situasi tertentu. Menurut Wardhani (2007), penelitian tindakan kelas adalah penelitian yang dilakukan oleh guru di dalam kelasnya sendiri melalui refleksi diri, dengan tujuan memperbaiki kinerjanya sebagai guru, sehingga hasil belajar siswa menjadi meningkat. Data penelitian ini dikumpulkan dengan observasi, hasil tes, diskusi dan dokumentasi.

\section{HASIL}

\section{Deskripsi Siklus I}

1. Perencanaan

Penggunaan pendekatan realistik dalam perencanaan pembelajaran matematika disusun dan diwujudkan dalam bentuk Rencana Pelaksanaan Pembelajaran (RPP). Perencanaan ini disusun berdasarkan program semester kedua sesuai dengan penelitian berlangsung. Perencanaan pembelajaran disusun untuk alokasi waktu 2 x pertemuan yaitu 5 x 35 menit. Materi diambil dari kurikulum SD 2006, Kurikulum Tingkat Satuan Pendidikan (KTSP) mata pelajaran matematika kelas I semester II.

\section{Pelaksanaan}

Pelaksanaan yang diawali dengan melakukan tanya jawab tentang perkalian dan pembagian dengan menggunakan kartu matematika dapat memotivasi siswa dalam melaksanakan pembelajaran sehingga siswa dapat menjawab pertanyaan berdasarkan pengetahuan yang dimilikinya. Selanjutnya guru menyebutkan tujuan pembelajaran tentang manfaatnya mempelajari perkalian dan pembagian. Selanjutnya guru membagi siswa dalam 5 kelompok. Setiap kelompok berjumlah 5 orang. Setelah itu guru memberikan LKS kepada masing-masing kelompok seperti yang terlampir. Kemudian guru meminta siswa duduk dalam kelompoknya yang terdiri dari 5 orang pada setiap kelompok, masing-masing kelompok diberikan LKS. Selanjutnya guru menugasi masing-masing kelompok membaca dan memahami isi LKS yang diberikan, masing-masing kelompok mencatat hasil yang ditemukan dari LKS yang diberikan dan memcatatnya dalam lembar LKS yang tersedia. Siswa memulai kegiatan menyelesaikan masalah yang ada pada LKS dengan berdiskusi dalam kelompoknya. Guru mengarahkan siswa untuk aktif bekerja dalam kelompok. Pada kegiatan akhir, guru membimbing siswa untuk menyimpulkan pembelajaran tentang operasi hitung campuran yang berkaitan dengan perkalian dan pembagian. Selanjutnya siswa diberikan tes akhir. Tes akhir dilakukan bersama-sama dalam kelas secara individual.

\section{Pengamatan}

\section{1) Aktivitas Guru}

Kegiatan ini diawali dengan kegiatan membuka pelajaran berupa menyiapkan kondisi kelas untuk belajar dengan mempersiapkan segala sesuatu yang berhubungan dengan pembelajaran yang akan dilaksanakan, dimana guru memeriksa kelengkapan LKS dan media 
yang akan digunakan. Kemudian guru mengecek kehadiran siswa, dan guru menyampaikan tujuan pembelajaran tentang operasi hitung campuran. Pada pelaksanaan tahap pendahuluan, membangkitkan skemata siswa yaitu tanya jawab tentang masalah sehari-hari siswa, yang berkaitan dengan operasi hitung menyangkut perkalian dan pembagian. Kemudian pada tahap inti pertemuan II, guru meminta siswa duduk dalam kelompoknya yang terdiri dari 5 orang pada setiap kelompok, masing-masing kelompok diberikan LKS. Kemudian guru membagikan media yang akan digunakan pada masing-masing kelompok yaitu 2 kotak pensil, 5 kantong kelereng, 3 ikat gelang karet. Kegiatan akhir yaitu pelaksanaan tahap penutup, guru membimbing siswa untuk menyimpulkan pembelajaran tentang operasi hitung campuran yang berkaitan dengan perkalian dan pembagian. Selanjutnya siswa diberikan tes akhir. Tes akhir dilakukan bersama-sama dalam kelas secara individual.

\section{2) Aktivitas Siswa}

Dari segi aktivitas siswa, pengamat melaporkan sebagai berikut: a) siswa masih belum aktif untuk mengikuti pembelajaran, hal ini dapat dilihat siswa masih belum maksimal menanggapi pertanyaan yang diberikan oleh guru dengan baik, b) Siswa bekerja dalam kelompok dengan baik tetapi tidak semua siswa yang serius, ini terlihat dengan banyaknya siswa yang bermain-main saat berdiskusi, c) Dalam melakukan diskusi masih didominasi oleh siswa yang pintar, begitu juga dalam mengisi LKS hanya diisi oleh satu orang saja, d) Pada saat siswa disuruh melaporkan hasil diskusi, siswa kurang antusias ke depan kelas karena malu untuk melaporkan hasil diskusinya, e) siswa masih malu-malu dalam mengemukakan pendapatnya, ini terlihat saat menanggapi laporan hasil diskusi hanya satu siswa saja yang berani menanggapi. Hal ini membuktikan siswa belum aktif untuk mengikuti belajar. Berdasarkan uraian diatas dapat disimpulkan bahwa siklus I belum memperoleh hasil yang memuaskan (belum berhasil). Keberhasilan persentase yang diharapkan adalah baik. Dari hasil diskusi peneliti dengan kolabolator perlu dilanjutkan ke siklus II. Akan direncanakan dan dilaksanakan dengan lebih baik.

\section{3) Hasil Belajar}

Observasi keberhasilan tindakan diamati selama dan sesudah tindakan dilaksanakan. Hal ini dilaksanakan untuk mendapatkan informasi dari observer terhadap pelaksanaan pembelajaran pada siklus I baik pelaksanaan, evaluasi dan hasil yang diperoleh oleh siswa. Berdasarkan pengamatan observer hasil diskusi dengan peneliti, pada tindakan siklus I ditemukan masih ada siswa yang belum ikut secara aktif menyelesaikan masalah realistik yang diberikan. Selain itu juga ditemukan adanya beberapa siswa yang belum berani mengemukakan pendapatnya, siswa lebih suka mendengar dan memperhatikan temannya berdiskusi.

Keadaan kelas memang agak ribut dan waktu banyak terbuang untuk mengatur siswa. dan siswa masih ada yang belum aktif mengikuti kegiatan pembelajaran secara individual dan pada kelompoknya. Namun demikian secara umum ditemukan bahwa siswa secara klasikal senang belajar dengan pendekatan realistik. Siswa lebih cepat memahami masalah dengan adanya kegiatan dan kebebasan dalam bekerja. Apalagi siswa diberi kesempatan bertanya dan memperhatikan kelompok lain untuk menyampaikan hasil evaluasi dan LKSnya. Dalam pembelajaran siswa terlihat senang jadi tidak mengantuk dan waktupun terasa cepat berlalu, sehingga tidak menimbulkan kejenuhan. Evaluasi hasil yang diperoleh pada siklus I mencapai $77,2 \%$. Hal ini disebabkan ada sebagian yang siswa masih mengalami kesulitan dalam menjawab soal mengenai perkalian dan pembagian dan mengenai operasi hitung campuran dalam pembelajaran melalui pendekatan matematika realistik.

\section{Refleksi}

Kegiatan refleksi dilakukan secara kolaboratif antara peneliti dan kepala sekolah, setiap pembelajaran berakhir. Pada kesempatan ini temuan dan hasil pengamatan peneliti dibahas bersama. Refleksi tindakan siklus I ini mencakup refleksi terhadap perencanaan, pelaksanaan, evaluasi dan hasil yang diperoleh oleh siswa. Refleksi terhadap perencanaan yakni sebagai berikut: dilihat dari hasil paparan siklus I diketahui bahwa perencanaan pembelajaran terlaksana dengan cukup baik. Sebahagian dari langkah pada perencanaan terlaksana sesuai 
dengan yang diinginkan. Tapi terdapat beberapa langkah yang tidak berjalan baik. Contohnya, pada awal pembelajaran pertemuan II pembentukan kelompok menghabiskan waktu yang lama, peneliti kurang memberikan pengarahan tentang memindahkan masalah dalam bentuk matematika. Berdasarkan refleksi di atas dan hasil diskusi dengan kepala sekolah, pembelajaran yang diharapkan pada pembelajaran siklus I belum tercapai dengan baik. Upaya menggunakan pendekatan realistik dapat menentukan langkah-langkah proses pembelajaran yang akan ditargetkan pada siklus II.

\section{Deskripsi Siklus II}

\section{Perencanaan}

Berdasarkan hasil tindakan dari siklus I yang telah diuraikan di atas maka pada siklus II ini tindakan yang akan dilaksanakan yakni: 1) memperjelas penyampaian tujuan pembelajaran agar siswa lebih memahami materi yang akan di ajarkan. 2) Memperbanyak media dan diberikan kepada semua anggota kelompok sehingga masing-masing anggota kelompok dapat membaca dan memahami isi LKS dengan baik. 3) Masing-masing siswa dalam kelompok melakukan percobaan untuk penyelidikan. 4) Berusaha memaksimalkan pemakaian waktu dalam pembelajaran sesuai dengan rencana pembelajaran. 5) lebih memotivasi siswa agar dapat ikut aktif berdiskusi dalam kelompok.

\section{Pelaksanaan}

Proses pelaksanaan siklus II terbagi menjadi dua kali pertemuan. Pertemuan pertama berlangsung selama 2x35 menit dan pertemuan kedua berlangsung selama 3x35 menit.

\section{Pengamatan}

Pembelajaran pada pertemuan I siklus II ini diamati oleh kepala sekolah. Sedangkan proses pembelajarannya dilaksanakan oleh peneliti sendiri sebagai guru. Dimana kepala sekolah tersebut mengamati jalannya pelaksanaan pembelajaran dengan menggunakan lembar observasi aktivitas guru dan siswa. Pengamatan ini dilakukan secara berkelanjutan mulai dari tindakan awal pada petemuan I sampai tindakan akhir pada petemuan II. Hal ini dikarenakan oleh pengamatan terhadap satu tindakan akan berpengaruh pada tindakan yang lainnya.

\section{1) Observasi Aktivitas Guru}

Pelaksanaan pembelajaran diawali dengan melakukan tanya jawab tentang perkalian dengan menggunakan kartu matematika dapat memotivasi siswa dalam melaksanakan pembelajaran. sehingga siswa dapat menjawab pertanyaan berdasarkan pengetahuan yang dimilikinya. Selanjutnya guru menyebutkan tujuan pembelajaran tentang manfaatnya mempelajari perkalian tentang operasi hitung. Guru melakukan sebuah percontohan tentang operasi hitung dengan menggunakan media kelereng sebelum siswa melakukan diskusi kelompok. Tahap berikutnya adalah menempatkan siswa ke dalam 5 kelompok yang terdiri dari 5 orang (terlampir). Pembagian kelompok pada siklus II ini sama dengan siklus I. Selanjutnya masing-masing siswa duduk dalam kelompok masing-masing. Selanjutnya guru memberikan LKS kepada masing-masing kelompok dan membagikan media yang akan digunakan pada masing-masing kelompok yaitu 2 kotak pensil, 5 kantong kelereng, 3 ikat gelang karet, 5 kotak mainan mobil-mobilan sesuai dengan petunjuk LKS.

Kemudian pada tahap inti pertemuan II, selanjutnya guru menugasi masing-masing kelompok membaca dan memahami isi LKS yang diberikan. Masing-masing kelompok mencari hasil yang ditemukan dari LKS yang diberikan dan memcatatnya dalam lembar LKS yang tersedia, Siswa melakukan petunjuk yang ada pada LKS. Guru mengarahkan siswa untuk mencari penyelesaian masalah yang terdapat pada LKS dengan caranya sendiri dengan berdiskusi dalam kelompok. Masalah yang dibahas dalam pertemuan ini adalah melakukan operasi hitung campuran yang berkaitan dengan perkalian dan pembagian dengan menggunakan pensil, kelereng dan karet gelang yang disediakan oleh guru. Kegiatan akhir, pelaksanaan tahap penutup, guru membimbing siswa untuk menyimpulkan pembelajaran tentang operasi hitung campuran yang berkaitan dengan perkalian dan pembagian. Selanjutnya siswa diberikan tes akhir. Tes akhir dilakukan bersama-sama dalam kelas secara individual. Soal diberikan dalam bentuk evaluasi. 


\section{2) Observasi Aktivitas Siswa}

Dari segi aktivitas siswa, pengamat melaporkan sebagai berikut: 1) semua siswa serius mengikuti kegiatan diskusi dalam menyelesaiakan tugas yang diberikan oleh guru tentang cara melakukan operasi hitung perkalian dan pembagian bilangan dua, 2) siswa termotivasi dalam menyelesaikan evaluasi dan LKS yang telah dibagikan, 3) siswa nampak senang dalam bekerja, 4) siswa sudah berani dan bersemangat dalam mempresentasikan hasil diskusi kelompoknya meskipun melalui bimbingan gurunya, 5) siswa sudah aktif bekerja dalam kelompok, 6) siswa sudah membuat kesimpulan materi pelajaran, 7) tes akhir yang diberikan guru diselesaikan siswa tanpa mengalami kesulitan.

\section{3) Hasil Belajar Siswa}

Evaluasi hasil yang diperoleh pada siklus II mencapai rata-rata $88 \%$ dengan perincian sebagai berikut: 8 siswa (32\%) yang memperoleh nilai 100, 6 siswa (24\%) yang meperoleh nilai 90, 5 siswa (20\%) yang memperoleh nilai 85,3 pserta didik (12\%) yang memperoleh nilai 80,2 siswa (8\%) yang mendapat nilai 70, 1 siswa (4\%) yang memperoleh nilai 60. Ini berarti lebih dari $85 \%$ dari jumlah siswa yang mendapat nilai diatas 75 (88\% dari jumlah siswa). Data hasil belajar siswa pada siklus II dapat dilihat pada lampiran 26. Evaluasi hasil yang diperoleh pada siklus II $(88,2)$ mengalami peningkatan dibandingkan dengan tes pada siklus I $(77,2)$.

\section{Refleksi}

Kegiatan refleksi dilakukan secara kolaboratif antara peneliti, kepala sekolah setiap pembelajaran berakhir. Pada kesempatan ini temuan dan hasil pengamatan peneliti dibahas bersama. Refleksi tindakan siklus II ini mencakup refleksi terhadap perencanaan, pelaksanaan, evaluasi dan hasil yang diperoleh oleh siswa. Refleksi terhadap perencanaan yakni sebagai berikut: dilihat dari paparan siklus II diketahui bahwa perencanaan pembelajaran sudah lebih baik dari siklus I, serta dilaksanakan sesuai dengan langkah-langkah yang tertulis dalam perencanaan. Dari hasil belajar siswa yang meningkat, karena tidak ditemukan lagi siswa yang memperoleh nilai dalam $<70$. Nilai anak hanya berkisar di atas 70-100 dengan nilai rata-rata siswa 88. Jadi, dapat disimpulkan bahwa penelitian dalam pembelajaran siklus II telah melaksanakan tugas dengan baik. Hal ini dapat dilihat pada lampiran yaitu hasil belajar siswa pada siklus II. Dengan demikian penelitian ini berhenti pada siklus II dan tidak dilanjutkan pada siklus berikutnya.

\section{PEMBAHASAN}

\section{Siklus I}

Dari hasil penelitian pelaksanaan pembelajaran pendekatan matematika realistik pada pembelajaran melakukan operasi hitung campuran perkalian dan pembagian bilangan sampai dua angka pada mata pelajaran matematika kelas I Sekolah Dasar Unggul Terpadu Padang Pariaman. Dan terlihat dalam proses pembelajaran bahwa guru membuat rancangan pembelajaran dalam bentuk Rencana Pelaksanaan Pembelajaran (RPP). Rencana Pelaksanaan Pembelajaran merupakan rencana operasional pembelajaran yang memuat beberapa indikator yang terkait untuk dilaksanakan dalam satu atau beberapa kali pertemuan. Berdasarkan perencanaan yang disusun pelaksanaan pembelajaran dilaksanakan sesuai dengan apa yang telah direncanakan, yang mana pada siklus I pembelajaran disajikan dalam dua kali pertemuan (5x35menit). Pembelajaran pada siklus I dilaksanakan sesuai dengan tahap-tahap pembelajaran matematika realistik yaitu: 1) tahap pendahuluan, 2) tahap pengembangan model simbolik, 3) tahap penjelasan dan alasan, dan 4) tahap penutup. Berdasarkan catatan pada lembar observasi dan diskusi peneliti dengan pengamat penyebab dari masih rendahnya hasil belajar siswa pada siklus I secara garis besar adalah masih banyak siswa yang belum aktif dalam pembelajaran.

Setelah diperhatikan data hasil penelitian yang berkaitan dengan evaluasi pembelajaran, evaluasi yang dilakukan adalah evaluasi proses dan evaluasi hasil. Evaluasi proses pada setiap siklus dilakukan guru pada saat siswa berdiskusi. Berdasarkan hasil observasi aktivitas guru dan siswa dan diskusi peneliti dengan teman sejawat dan observer di atas, penyebab dari adanya siswa yang belum dapat menyelesaikan operasi hitung campuran disebabkan karena pembelajaran yang 
kurang menyenangkan dan guru kurang mengkonkretkan pembelajaran serta kurang melibatkan siswa dalam kegiatan pembelajaran operasi hitung campuran. Adapun belajar dengan kolaboratif secara langsung, dapat mendekatkan siswa pada situasi belajar yang diinginkan, membantu siswa kearah perkembangan kognitifnya. Dengan kegiatan ini, siswa mampu berlatih dan berbagi pengalaman, melatih keberanian mengeluarkan pendapat, dan bersedia mendengarkan.

Berdasarkan hasil pengamatan aktivitas guru, guru kurang memberikan motivasi kepada siswa untuk menyampaikan ide/gagasan yang ditemukannya. Guru juga kurang membimbing siswa dalam menyimpulkan materi pelajaran. Oleh sebab itu sebaiknya gurulah lebih memotivasi dan membimbing siswa untuk menyampaikan ide/gagasan yang mereka temukan dalam melakukan operasi hitung campuran. Guru harus membimbing siswa untuk membuat simpulan pembelajaran dan membimbing siswa untuk dapat memindahkan permasalahan dalam matematika. Hal ini karena siswa baru pertama kali melaksanakan pembelajaran seperti ini.

\section{Siklus II}

Rencana Pelaksanaan Pembelajaran (RPP) pada siklus II ini hampir sama dengan siklus I, namun dalam tahap penyelidikan, pengembangan materi, media yang digunakan dalam penyelidikan lebih dimaksimalkan. Pembelajaran melakukan operasi hitung dengan menggunakan pendekatan matematika realistik pada siklus II ini sudah berjalan dengan baik. Pembelajaran dipengaruhi oleh berbagai faktor seperti motivasi, kematangan, hubungan siswa dengan guru, kemampuan verbal, tingkat kebebasan, rasa aman, dan keterampilan guru dalam berkomunikasi. Oleh karena itu guru harus melakukan perbaikan dalam pelaksanaan pembelajaran disamping perbaikan pada RPP. Guru harus dapat memberikan motivasi kepada siswa dalam pembelajaran.

Dari hasil analisis penelitian siklus II sudah mencapai $88 \%$ dan nilai rata-rata kelas 88,2. Berdasarkan hasil pengamatan siklus II yang diperoleh maka pelaksanaan siklus II sudah baik dan guru sudah berhasil dalam usaha peningkatan hasil belajar matematika melalui pendekatan realistik bagi kelas Ic SDN 21 Batang Anai Kab. Padang Pariaman. Pembelajaran yang disajikan guru dalam memberikan motivasi dan bimbingan kepada siswa sangat bagus. Apalagi dengan guru menggunakan model pembelajaran realistik dimana model ini membuat siswa merasa senang, karena masalah yang mereka kerjakan berhubungan dengan kehidupan sehari-hari dan siswa dilibatkan dalam melakukan kegiatan pembelajaran. Di samping itu, guru juga memberi kesempatan kepada siswa untuk mengemukakan ide-ide yang telah mereka temukan dalam menyelesaikan permasalahan yanng diberikan. Untuk itu guru harus mampu menciptakan situasi yang menyenangkan untuk belajar.

Pada dasarnya, matematika adalah pemecahan masalah (problem solving), oleh sebab itu matematika sebaiknya diajarkan melalui berbagai masalah yang ada di lingkungan sekitar siswa. Dengan begitu siswa dapat terlatih berfikir dan berargumentasi. Melalui matematika, siswa dapat pula dibiasakan bekerja efisien, selalu berusaha mencari jalan yang lebih sederhana dan lebih mudah dipahaminya tanpa mengurangi keefektifannya. Untuk mencapai hal tersebut sudah seharusnya guru mampu menciptakan pembelajaran yang sesuai dengan kebutuhan siswa. Selain itu guru juga harus memperhatikan keberhasilan siswa dalam memahami sesuatu dengan cara sesuai dengan tingkat kemampuan siswa. Guru bertugas membelajarkan siswa, maka guru haruslah menggunakan berbagai macam cara agar pembelajaran dapat bermakna bagi siswa, seperti menggunakan pendekatan realistik, dimana siswa terlibat dalam melakukan kegiatan pembelajaran dan siswa menemukan sendiri konsep matematika. Pendekatan realistik dapat menciptakan suasana belajar yang menyenangkan bagi siswa.

\section{KESIMPULAN}

Pembelajaran matematika melalui pendekatan realistik terdiri dari 4 tahap. Pembelajaran menggunakan pendekatan realistik dibagi atas tiga kegiatan yaitu kegiatan awal, kegiatan inti, kegiatan akhir. Pada kegiatan awal dilaksanakan kegiatan tahap pendahuluan dan membagi kelompok. Pada kegiatan inti dilaksanakan tahap pengembangan model simbolik dan tahap penjelasan dan alasan. Pada kegiatan akhir dilaksanakan tahap penutup dimana siswa diarahkan untuk menyimpulkan pembelajaran dan memberikan tes akhir. Pendekatan realistik dapat 
memotivasi siswa untuk belajar dengan gembira, bebas, aktif, dan produktif, sehingga kendala psikologis yang sering menghambat siswa seperti rasa enggan, segan, takut, dan malu dapat teratasi.

Siswa terlatih berbagi pengalaman, aktif dalam belajar, berani menyampaikan ide/gagasan yang ditemukannya, dan bersedia mendengarkan pendapat orang lain, serta mau menerima perbedaan pendapat. Fungsi guru berubah dari seorang penyampai pengetahuan atau pemberi informasi menjadi fasilitator. Hal ini terlihat dalam penyajian pembelajaran guru yang semula selalu memberi penjelasan berubah menjadi fasilitator. Bentuk pembelajaran dengan pendekatan realistik dapat meningkatkan hasil belajar siswa. Meningkatnya hasil belajar siswa tersebut dapat dilihat dari rata-rata yang diperoleh pada siklus I yakni 77,2 dan pada siklus II mengalami peningkatan yaitu menjadi 88,2 .

\section{SARAN}

Bentuk pembelajaran matematika melalui pendekatan realistik layak dipertimbangkan oleh guru untuk menjadi pembelajaran alternatif yang dapat digunakan sebagai referensi dalam memilih pendekatan pembelajaran. Bagi guru yang ingin menerapkan pembelajaran dengan menggunakan pendekatan realistik, disarankan untuk menyesuaikan materi pembelajaran dengan konteks seharihari siswa. Guru juga perlu lebih kreatif dalam merancang pembelajaran yang sesuai dengan situasi dunia nyata, memberikan perhatian, bimbingan dan motivasi belajar secara sungguh-sungguh kepada siswa yang berkemampuan kurang dan pasif dalam kelompok karena siswa yang demikian sering menggantungkan diri pada temannya. Guru perlu menyiapkan sarana dan prasarana yang dikenali siswa, karena akan mempermudah siswa memahami masalah. Bagi peneliti selanjutnya disarankan untuk melakukan kajian mendalam tentang penerapan model pembelajaran dengan pendekatan realistik pada materi lain dalam matematika. Kepada kepala Sekolah Dasar dan pejabat terkait kiranya dapat memberikan perhatian kepada guru terutama dalam meningkatkan hasil belajar dalam proses pembelajaran.

\section{DAFTAR RUJUKAN}

Buyung. (2006). Peningkatan Pemahaman Terhadap Konsep Volume Balok Melalui Pendekatan matematika realistik Bagi Siswa Kelas V SD. PGSD UNP

Depdiknas. (2006). Kurikulum Tingkat Satuan Pendidikan Jenjang Pendidikan Dasar. Jakarta: Depdiknas.

Gravemeijer. (1994). Developing Realitics Mathematics Education. Utrecht: Freudenthal Institute.

Sardiman, A, M. (2006). Interaksi dan Motivasi Belajar-Mengajar. Jakarta: PT Raja Grafindo Persada.

Suharsimi, Arikunto, dkk. (2006). Penelitian Tindakan Kelas. Jakarta: Bumi Aksara

Sutarto, Hadi. (2007). Pendidikan Matematika Realistik. Banjarmasin: Tulip. 